\title{
Bronchoalveolar inflammation after exposure to diesel exhaust: comparison between unfiltered and particle trap filtered exhaust
}

B Rudell, A Blomberg, R Helleday, M-C Ledin, B Lundbäck, N Stjernberg, P Hörstedt, T Sandström

\begin{abstract}
Objectives-Air pollution particulates have been identified as having adverse effects on respiratory health. The present study was undertaken to further clarify the effects of diesel exhaust on bronchoalveolar cells and soluble components in normal healthy subjects. The study was also designed to evaluate whether a ceramic particle trap at the end of the tail pipe, from an idling engine, would reduce indices of airway inflammation.

Methods-The study comprised three exposures in all 10 healthy never smoking subjects; air, diluted diesel exhaust, and diluted diesel exhaust filtered with a ceramic particle trap. The exposures were given for 1 hour in randomised order about 3 weeks apart. The diesel exhaust exposure apperatus has previously been carefully developed and evaluated. Bronchoalveolar lavage was performed 24 hours after exposures and the lavage fluids from the bronchial and bronchoalveolar region were analysed for cells and soluble components.
\end{abstract}

Results-The particle trap reduced the mean steady state number of particles by $50 \%$, but the concentrations of the other measured compounds were almost unchanged. It was found that diesel exhaust caused an increase in neutrophils in airway lavage, together with an adverse influence on the phagocytosis by alveolar macrophages in vitro. Furthermore, the diesel exhaust was found to be able to induce a migration of alveolar macrophages into the airspaces, together with reduction in $\mathrm{CD} 3+\mathrm{CD} 25+$ cells. $(\mathrm{CD}=$ cluster of differentiation) The use of the specific ceramic particle trap at the end of the tail pipe was not sufficient to completely abolish these effects when interacting with the exhaust from an idling vehicle.

Conclusions-The current study showed that exposure to diesel exhaust may induce neutrophil and alveolar macrophage recruitment into the airways and suppress alveolar macrophage function. The particle trap did not cause significant reduction of effects induced by diesel exhaust compared with unfiltered diesel exhaust. Further studies are warranted to evaluate more efficient treatment devices to reduce adverse reactions to diesel exhaust in the airways.

(Occup Environ Med 1999;56:527-534)

Keywords: diesel exhaust; neutrophils; macrophages; phagocytosis; bronchoalveolar lavage; particle trap

The World Health Organisation and the United Nations Environment Programme have stated that particulate matter is the most serious air pollution problem globally. Most of the world's megacities have very high concentrations of particulates in ambient air, with annual averages of $200-600 \mu \mathrm{g} / \mathrm{m}^{3}$, and considerably higher peak concentrations. ${ }^{1}$ Air pollutants and in particular particulate matter have been strongly associated with adverse effects on respiratory health. Airway symptoms, exacerbations of asthma and chronic obstructive pulmonary disease (COPD), emergency department visits, and hospital admissions have been associated with increases in particulate air pollution, which is also the case for cardiac and respiratory death rates. ${ }^{2}$ Diesel engines contribute considerably to the air pollution, producing up to 100 times more particulates than comparable petrol engines. ${ }^{4}$ The diesel exhaust also constitutes various other components - such as nitric oxide (NO), nitrogen dioxide $\left(\mathrm{NO}_{2}\right)$, carbon monoxide (CO), formaldehyde, and thousands of other hydrocarbons (HCs). Workers exposed to diesel exhaust have shown an increased prevalence of symptoms of the eyes and the nose, headache, nausea, difficult breathing, cough, phlegm, and wheezing. ${ }^{5}$ Increased airway resistance and reversible reductions in $\mathrm{FEV}_{1}$ (forced expiratory volume in 1 second) and FVC (forced vital capacity) have also been reported. ${ }^{6}$

In earlier studies we have reported on the use of an apparatus for controlled exposures to diluted diesel exhaust in humans. The studies have evaluated the effects of diesel exhaust on symptoms, lung function, and constituents of bronchoalveolar lavage (BAL).$^{7-9}$ Our exposure apparatus has been carefully studied and been shown to preserve the composition of the diesel exhaust, measured as concentration ratios of various components in the exhaust, and not to cause any detectable changes in particles during the passage to the exposure chamber. ${ }^{8}$ Although several experimental studies with BAL after controlled exposures to sulphur dioxide $\left(\mathrm{SO}_{2}\right), \mathrm{NO}_{2}$, and ozone $\left(\mathrm{O}_{3}\right)$ have been conducted in humans ${ }^{10}$ only one study has so far been published on BAL after exposure to 
diesel exhaust. ${ }^{7}$ In the study the subjects were exposed for 1 hour in an exposure chamber to $1.6 \mathrm{ppm} \mathrm{NO}_{2}$ and $4 \times 10^{6}$ particles of $<1 \mu \mathrm{m}$ diameter $/ \mathrm{cm}^{3}$, comparable with exposure situations reported at certain workplaces. ${ }^{561112}$ Bronchoalveolar lavage was performed 18 hours after exposure. Analysis of BAL fluid showed that diluted diesel exhaust, from an idling engine, caused an increase in bronchoalveolar neutrophils, as well as a reduction in phagocytosis by alveolar macrophages in vitro.

As diesel exhaust has been shown to cause unwanted biological effects, steps have been taken to reduce these effects by limiting harmful components. One such approach is to reduce the particle numbers by using a ceramic particulate trap. The present study was undertaken to further clarify the effects of diesel exhaust on bronchoalveolar cells and soluble components in normal healthy subjects. The study was also designed to evaluate if a ceramic particle trap at the end of the tail pipe of an idling engine would reduce indices of airway inflammation. The study comprised three exposures in all people; air, diluted diesel exhaust, and diluted diesel exhaust filtered with a ceramic particle trap. The study was based on certain workplace and outdoor exposure conditions, as well as earlier experimental exposure experiences. ${ }^{5-14}$

\section{Methods}

DESIGN OF THE STUDY

Ten healthy never smoking subjects, eight men and two women, (mean (range) 27 (22-35) years) with normal lung function and without airway infection for at least 6 weeks before the study were included. Each subject underwent three different exposures; once to air, once to unfiltered diesel exhaust in the exposure chamber, and once to diesel exhaust filtered with a ceramic particle trap at the end of the tail pipe. The diesel exhaust used for exposure was diluted as previously described. ${ }^{7-9}$

The exposure sequence was randomised and blinded to all but one of the investigators who arranged the exposure apparatus, connected and disconnected the particle trap, and also monitored the exposure variables. The exposures lasted for 1 hour with the subjects performing light exercise on a bicycle ergometer at $75 \mathrm{~W}$, giving a minute ventilation of about $15 \mathrm{l} / \mathrm{min} / \mathrm{m}^{2}$ body surface.

Rest and exercise alternated every 10 minutes. Fibreoptic bronchoscopy with BAL was performed 24 hours after the start of each exposure and about 3 weeks separated the exposures. The subjects were recruited through advertisements in the local newspaper and at the University. All participants gave their informed consent and the study was approved by the local Ethics Committee.

BAL

Flexible fibreoptic bronchoscopy with BAL was performed in the right middle lobe. This procedure as well as the processing of the BAL fluid and the staining of cells has been previously described in detail. ${ }^{15}$ In brief, the first recovered $20 \mathrm{ml}$ of the first instilled aliquot of $60 \mathrm{ml}$ phosphate buffered saline (PBS) was analysed separately and defined as the bronchial portion. The remaining recovered fluid of the totally instilled $4 \times 60 \mathrm{ml}$ was defined as the bronchoalveolar portion. After counting the total cells, cell differentials were obtained from cytospin slides. The supernatants were frozen and stored at $-70^{\circ} \mathrm{C}$ until analysis of soluble components. Flow cytometry for determination of lymphocyte subsets was performed on cells from the bronchoalveolar portion, as there were not enough cells for this analysis in the bronchial portion.

Phagocytosis by alveolar macrophage Phagocytosis by alveolar macrophages was measured as the percentage engulfment of positive cells. A glass surface adherence method was used as described elsewhere. ${ }^{16}$ The method was modified for the use of BAL cells. Briefly, 200000 cells in $200 \mu \mathrm{l}$ medium containing $10 \%$ pooled human $\mathrm{AB}+$ serum were allowed to adhere to a glass surface for 30 minutes in cell culture conditions. After rinsing the non-adherent cells away, yeast cells labelled with fluroescinthiocyanate and opsonised with human serum where added to the slides $(2.5 \times$ $10^{7}$ yeast cells in PBS, $\mathrm{pH}$ 7.4). After 30 minutes the phagocytosis was stopped by dipping the slides in ice cold PBS containing 1 mM EDTA. The fluorescence of non-ingested yeast cells was quenched by dripping toluidine blue in saline $(1 \mathrm{mg} / \mathrm{ml}, \mathrm{pH} 4.7)$ on to the slides. Yeast cell adherence (attachment) to an alveolar macrophage was defined as visible contact between a brown yeast cell and an alveolar macrophage. Engulfment was defined as the presence of fluorescent yeast cells within an alveolar macrophage.

\section{EXPERIMENTAL DESIGN}

A schematic view of the experimental setup is shown in figure 1 and it has been previously described in detail. ${ }^{8}$ The continuously idling truck was parked outdoors and the tailpipe was connected to a shunt and dilutor (length (1) = $0.8 \mathrm{~m}$, diameter $(\mathrm{d})=100 \mathrm{~mm})$. When filtering the exhaust a ceramic particle trap was inserted between the tail pipe and the shunt and dilutor. The other end of the shunt and dilutor was connected to a tube $(1=6 \mathrm{~m}, \mathrm{~d}=100 \mathrm{~mm})$ to the exposure chamber $(3 \times 3 \times 2.3 \mathrm{~m})$. The exposure chamber was continuously evacuated with a waste fan. There was a valve in the shunt tube and an adjustable diaphragm between the shunt and the dilutor. Air for dilution was continuously fed into the system with a fan. The flow of diesel exhaust to dilution was a function of valve and diaphragm openings. After a warming up period when the engine was idling, with or without the ceramic particulate trap connected, a part of the exhaust from a continuously idling diesel engine was continuously diluted with air and fed into the exposure chamber.

The steady state concentration in the exposure chamber was reached within 10 minutes and the chamber air volume was changed every 2-3 minutes. The composition of the diesel exhaust measured as particles, $\mathrm{NO}_{2}, \mathrm{NO}, \mathrm{CO}$, 


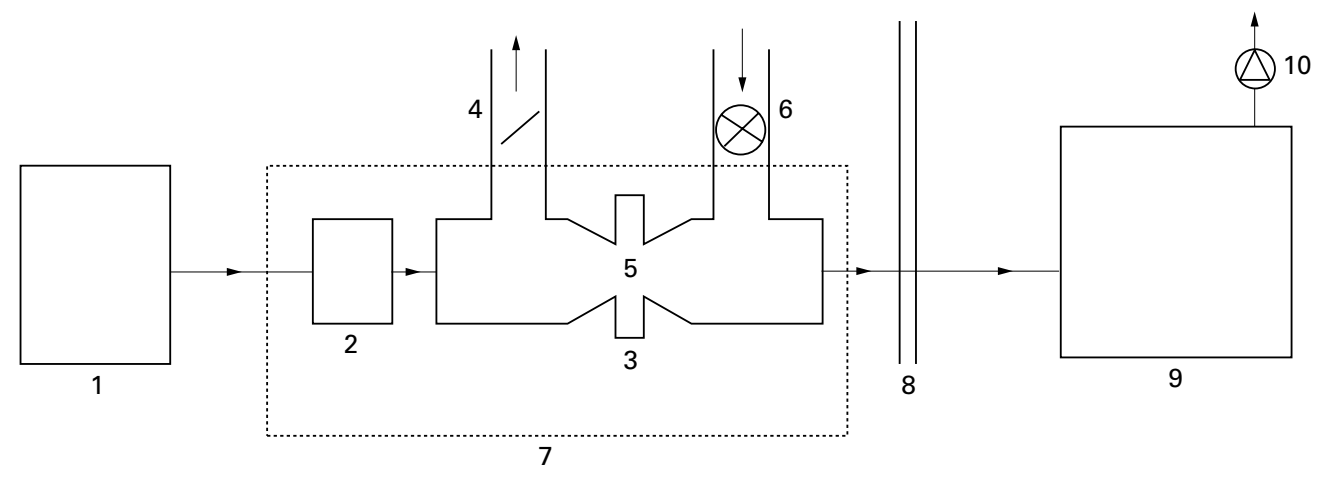

A

B

Figure 1 Schematic view of the experimental design. Arrow=flow direction; $A=$ outdoors; $B=$ indoors; $1=$ continuously idling truck; $2=$ ceramic particle trap at the end of the tail pipe; $3=$ shunt and dilutor; $4=$ shunt tube with the valve; $5=$ adjustable diaphragm; $6=$ air dilutor tube with the fan; $7=$ electric heating $\left(200^{\circ} \mathrm{C}\right) ; 8=$ wall between chamber hall and outdoors; $9=$ exposure chamber $(3 \times 3 \times 2.3 \mathrm{~m}) ; 10=$ air evacuation fan.

HCs, and formaldehyde in the exposure chamber has previously been shown to be constant throughout 3 hours of running. ${ }^{8}$ The exposure conditions were primarily based on work situations in which subjects are exposed to diesel exhaust from idling vehicles. Such situations may yield considerable air pollution, especially in spaces with stagnant air. The efficacy of equipment reducing exhaust may be of particular importance under such circumstances.

Exposure to air

The subjects were exposed to air through the exposure system. A new tube, free from the smell of diesel exhaust from earlier exposures, was used to feed the air into the exposure chamber, and new plastic foil chamber walls were used to avoid smell from old diesel exhaust. Due to the sound from the evacuation fan in the exposure chamber it was not possible for the subjects to hear whether the engine outdoors was running or not.

Exposure with the particle trap

Figure 2 shows the ceramic particle trap and the two conical cylinders between the tail pipe and the shunt and dilutor. The smaller diameter (inner diameter $=65 \mathrm{~mm}$ ) of the conical cylinder $(1=380 \mathrm{~mm})$ was fixed to the tail pipe. The larger diameter (inner diameter $=$ $140 \mathrm{~mm}$ ) was connected to the cylindrical trap $(1=200 \mathrm{~mm}$, inner diameter $=140 \mathrm{~mm})$. An identical conical cylinder was inserted at the other end of the trap. This cylinder was connected to the shunt and dilutor through a

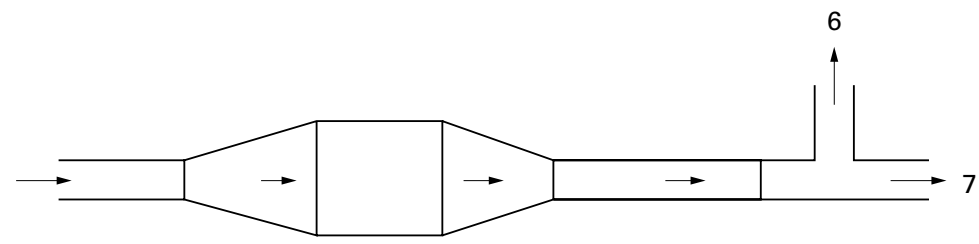

1 2 3 2 4 5

Figure 2 Schematic view of the exhaust particle trap and the connections to the tail pipe, shunt, and dilutor. Arrow =flow direction; $1=$ tail pipe; $2=$ conical cylinders; $3=$ ceramic particle trap; 4=flexible tube; 5=part of shunt and dilutor; $6=$ shunt tube; $7=$ to air dilution and exposure chamber. flexible tube $(1=800 \mathrm{~mm}$, inner diameter $=$ $100 \mathrm{~mm}$ ). The tubes, cylinders, and the outer shell of the trap were metal and their outer surfaces were heated to about $200^{\circ} \mathrm{C}$ to avoid condensation and changes in the exhaust composition. It has previously been shown that the size and the shape of the particles do not change in the metallic tube, shunt, and dilutor, or in the tube to the exposure chamber. ${ }^{8}$

Exposure without the particle trap

The device was identical to exposure with the trap except that the conical cylinders were connected to each other without the trap between.

\section{Particle trap}

A schematic presentation of the ceramic particle trap, Corning Ex-54 (Corning, New York,
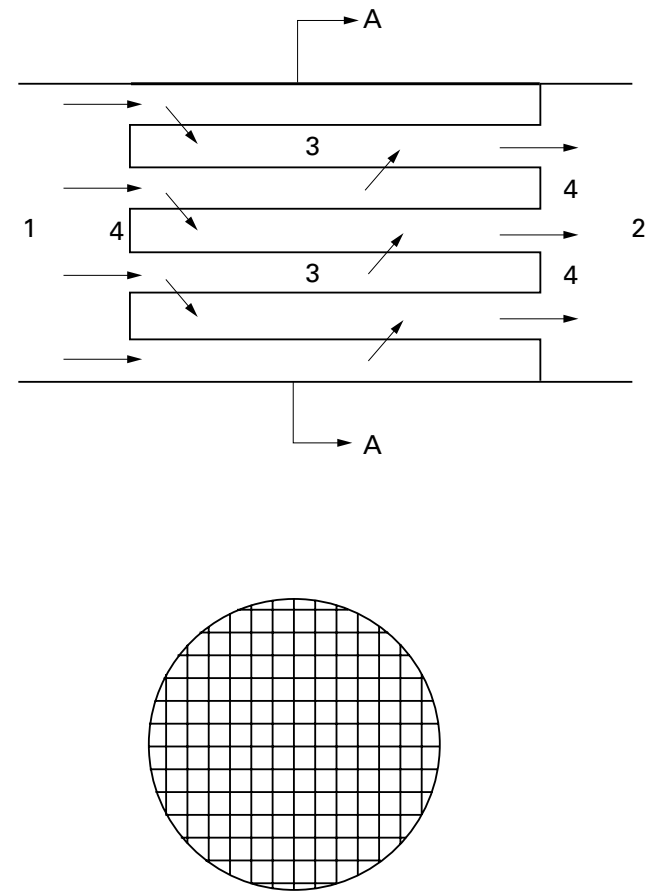

5

Figure 3 Schematic view of the ceramic particle trap. Arrow $=$ flow direction; $1=$ exhaust inlet; $2=$ exhaust outlet; $3=$ porous ceramic cell walls; $4=$ ceramic plugs; $5=$ side view of the trap through plane $A$. 
USA), is shown in figure 3. The trap has a honeycomb structure and channels with porous ceramic walls. It is housed in a metal container shell. Every second channel was open and the other channels were plugged with ceramic material at the inlet of the particle trap. The outlet of the filter was opposite to the inlet. Gases have to pass the ceramic wall before they can leave the trap through the open channels at the outlet of the trap.

The Corning Ex-54 had a mean pore size of $22 \mu \mathrm{m}$ and $50 \%$ total porosity. The area of each channel in the trap was $1.9 \times 1.9 \mathrm{~mm}$ and the thickness of the wall between two channels was $0.64 \mathrm{~mm}$. Two identical traps were used for the tests. The mechanical filter, porous ceramic walls, in the trap accumulated particles with time. To avoid a change in particle content in the exhaust and an overload of particles with too large a pressure drop in the trap the traps were regenerated after 4 hours of idling at Volvo, Gothenburg, Sweden.

Vehicle, motor oil, and fuel

The engine used for the tests was a new Volvo TD1F Intercooler model 1990, a six cylinder, four stroke, directly injected turbocharged diesel engine. At the time of the challenge tests the truck had been driven $5500 \mathrm{~km}$. During the exposures it was idling outdoors at $900 \mathrm{rpm}$. Vehicle data: displacement $5.48 \mathrm{dm}^{3}$, bore $98.43 \mathrm{~mm}$, stroke $120 \mathrm{~mm}$, compression ratio $16: 1$, economy speed range $1500-2400 \mathrm{rpm}$, output at $2800 \mathrm{rpm}$, net ISO/SAE $152 \mathrm{~kW}$, torque at $1600 \mathrm{rpm}$, net ISO/SAE $620 \mathrm{Nm}$. Smoke requirements conformed with ECE/ EEC regulations, US Federal register, and the Swedish norms. The motor oil was Mobil, Delvac 1400S, 15-40 W. A low sulphur fuel, OK Promil 2 (OK Petroleum, Stockholm, Sweden), with the major characteristics: $8 \mathrm{ppm}$ sulphur, $16 \%$ by vol aromatics, $<0.5 \%$ by vol olefins, $<0.02 \%$ by vol PAH, centane number 50,1 ppm nitrogen, and start boiling point, end boiling point, and $95 \%$ boiling point were 185 , 280 , and $265^{\circ} \mathrm{C}$, respectively, was used.

Analyses

The concentrations of particles (number $/ \mathrm{cm}^{3}$ ), $\mathrm{NO}_{2}, \mathrm{NO}, \mathrm{CO}$, and HCs were continuously recorded in the exposure chamber as previously described. ${ }^{9}$ A Miran 1-A, an IRinstrument (Foxboro, East Bridgewater, MA, USA), was used for analysis of $\mathrm{CO}$. NO and $\mathrm{NO}_{2}$ were analysed with a chemiluminiscence instrument, model 1600 oxides of nitrogen analyser (Columbia Scientific Industries, Austin, TE, USA). The HCs were analysed with the FID instrument, model 3-300 (JUM Engineering $\mathrm{GmbH}$, München, Germany) with a heated prefilter $\left(180^{\circ} \mathrm{C}\right)$ and calibrated with propane. X-Y recorders were used. Formaldehyde was collected on glass fibre filters (diameter $=13 \mathrm{~mm}$ ) impregnated with 2,4-dinitrophenylhydrazine ${ }^{17}$ and analysed by high performance liquid chromatography (HPLC), model WISP 712 (Millipore Co, Milford, MA, USA).

\section{Condensation particle counter}

Continuous registration of the number of particles $<1 \mu \mathrm{m}$ diameter $/ \mathrm{cm}^{3}$ was obtained with a condensation particle counter, model 3022 (TSI, St Paul, MN, USA) connected to a printer.

Scanning electron microscopy of particles

The particles in the exposure chamber were collected for 1.5 hours at $1 \mathrm{l} / \mathrm{min}$ on polycarbonate membrane Poretic filters, with a diameter of $25 \mathrm{~mm}$ and pore diameter of $0.4 \mu \mathrm{m}$. The size and the shape of the particles were assessed on scanning electron micrographs as previously outlined. ${ }^{8}$

\section{Differential mobility particle sizer}

The differential mobility particle sizer system (TSI, St Paul, MN, USA) including a computer, CPC and an electrostatic classifier, model 3071, (TSI, St Paul, MN, USA) was used on a separate occasion to estimate the number of particles as a function of the size once with and once without the particle trap, respectively. Particles within the size interval $0.017-0.9 \mu \mathrm{m}$ were recorded, and the computer system calculated the geometric mean electrical mobility equivalent diameter for the number, surface, and volume of the particles in the exposure chamber.

\section{STATISTICS}

On the basis of earlier studies, the primary end points were predetermined as changes in neutrophil numbers in BAL together with changes in macrophage phagocytosis in vitro. Wilcoxon's non-parametric rank sum test, for paired observations within the same person, was used to compare changes after exposures to the the two types of diesel exhaust versus exposure to air. The same test was used to compare the differences between the ratios of the two types of exposure to diesel exhaust and to air. A p value $<0.05$ was considered to be significant.

\section{Results}

The mean steady state exposure concentrations in the exposure chamber are shown in table 1. The $\mathrm{NO}_{2}$ concentrations were kept at mean $1.2 \mathrm{ppm}$ and $1.3 \mathrm{ppm}$ with and without the particle trap, respectively. The concentra-

Table 1 Steady state concentrations in the exposure chamber during exposure to air and diluted diesel exhaust with and without the particle trap (mean (SD))

\begin{tabular}{lclllll}
\hline & $\begin{array}{l}\text { Particles } \\
\times 10^{6} / \mathrm{cm}^{3}\end{array}$ & $\begin{array}{l}\mathrm{NO}_{2} \\
p p m\end{array}$ & $\begin{array}{l}\mathrm{NO} \\
p p m\end{array}$ & $\begin{array}{l}\mathrm{CO} \\
p p m\end{array}$ & $\begin{array}{l}\text { Hydrocarbons } \\
p p m\end{array}$ & $\begin{array}{l}\text { Formaldehyde } \\
m g / \mathrm{m}^{3}\end{array}$ \\
\hline Air & $<0.01$ & $<0.02$ & $<0.02$ & $<2$ & $<1$ & $<0.005$ \\
Exhaust without particle trap & $2.6(0.4)$ & $1.3(0.3)$ & $3.4(0.4)$ & $18(4)$ & $4.2(0.2)$ & $0.32(0.03)$ \\
Exhaust with particle trap & $1.3^{\star \star \star}(0.1)$ & $1.2(0.2)$ & $3.5(0.3)$ & $19(3)$ & $4.0(0.2)$ & $0.33(0.06)$ \\
\hline
\end{tabular}

$\star \star \star \mathrm{p}<0.001 \mathrm{v}$ without particle trap. 
Table 2 Lavage cell data in the bronchial portion (BP) before and after exposure to diesel exhaust with and without particle trap v exposure to air (medians (interquartile ranges))

\begin{tabular}{|c|c|c|c|c|c|c|c|c|c|c|c|}
\hline & \multirow{2}{*}{$\begin{array}{l}\text { Total cells } \\
\times 10^{7} / l\end{array}$} & \multicolumn{2}{|c|}{ Macrophages } & \multicolumn{2}{|c|}{$\begin{array}{l}\text { Lysosomes+ } \\
\text { macrophages }\end{array}$} & \multicolumn{2}{|c|}{ Lymphocytes } & \multicolumn{2}{|c|}{ Neutrophils } & \multicolumn{2}{|l|}{ Mast cells } \\
\hline & & $\times 10^{7} / l$ & $\%$ & $\times 10^{7} / l$ & $\%$ & $\times 10^{7} / l$ & $\%$ & $\times 10^{7} / l$ & $\%$ & $\times 10^{7} / l$ & $\%$ \\
\hline \multirow[t]{2}{*}{ Air exposure } & 15 & 13.4 & 94 & 1.1 & 9 & 0.8 & 5 & 0.2 & 1 & 0.7 & 5 \\
\hline & $10-17$ & $9.4-19.4$ & $90-95$ & $0.9-1.3$ & $7-13$ & $0.4-1.0$ & $3-8$ & $0.2-0.6$ & $1-4$ & $0.3-1.0$ & $2-7$ \\
\hline \multirow{2}{*}{$\begin{array}{l}\text { Diesel exhaust } \\
\text { (filtered) }\end{array}$} & 16 & 13.8 & 90 & 1.4 & 10 & 0.8 & 6 & $0.7 \dagger$ & $4^{\star}$ & 0.6 & 3 \\
\hline & $13-22$ & $12.2-21.0$ & $87-94$ & $0.7-2.0$ & $6-12$ & $0.4-1.7$ & $3-8$ & $0.3-1.3$ & $2-6$ & $0.3-1.1$ & $2-9$ \\
\hline \multirow{2}{*}{$\begin{array}{l}\text { Diesel exhaust } \\
\text { (unfiltered) }\end{array}$} & $19^{\star}$ & $16.8^{\star}$ & 89 & $1.7^{\star \star \star}$ & $10^{\star}$ & 1.1 & 6 & $0.8^{\star \star}$ & $5^{\star \star}$ & 0.4 & 3 \\
\hline & $17-23$ & $14.6-18.9$ & $88-91$ & $1.3-1.9$ & $9-13$ & $0.8-1.7$ & $4-8$ & $0.6-1.2$ & $2-6$ & $0.3-0.7$ & $1-3$ \\
\hline
\end{tabular}

${ }^{\star} \mathrm{p}<0.05 ;{ }^{\star \star} \mathrm{p}<0.02 ;{ }^{\star \star \star} \mathrm{p}<0.01 ; \mathrm{tp}=0.066 v$ exposure to air.

tions of $\mathrm{NO}, \mathrm{NO}_{2}, \mathrm{CO}, \mathrm{HCs}$, and formaldehyde were almost unchanged during the two types of exposures to diesel exhaust.

Concentrations in air of the measured substances were relatively low compared with the two diesel exhaust regimes.

There are many different physical methods characterising particles. Methods often characterised only a part of the particle-such as the diameter-but using different techniques and measuring different ranges of particle size, the data generated may not be exactly comparable. Particles in this study were characterised with at least three different methods. The methods were; continuous particle counting $(<1 \mu \mathrm{m}$, over $10^{6} / \mathrm{cm}^{3}$ ), differential mobility particle sizer calculating the geometric mean electrical mobility equivalent diameter $(\mu \mathrm{m})$ of particles $<0.9 \mu \mathrm{m}$, and scanning electron microscopy showing particle number in the range of $0.4-2$ $\mu \mathrm{m}$ on the surface of a filter.

The ceramic trap at the end of the tail pipe reduced the concentration of particles $<1 \mu \mathrm{m}$ in diameter (number $/ \mathrm{cm}^{3}$ ) by $50 \%$ versus unfiltered exhaust $(p<0.001)$. The traps were controlled by an engine manufacturer's engineer before and after each exposure period of more than 4 hours without finding any overload of particles. Particles collected on Poretic filters with pore size $0.4 \mu \mathrm{m}$ in the exposure chamber during the exposures to diluted diesel exhaust with and without the trap were counted on scanning electron micrographs. The numbers of larger particles $0.4-2$ $\mu \mathrm{m}$ were reduced by the ceramic trap by an average of $25 \%$ with a tendency towards significance $(p=0.055)$ compared with unfiltered exhaust. The differential mobility particle sizer measurements of the diesel exhaust were obtained and geometric mean electrical mobility equivalent diameters were determined. For the exposure once with and once without the particle trap the calculated geometric mean electrical mobility equivalent diameter for particle number were 0.041 and $0.044 \mu \mathrm{m}$, respectively. The corresponding geometric mean diameters for particle surface were 0.062 and $0.070 \mu \mathrm{m}$, and for particle volume 0.11 and $0.13 \mu \mathrm{m}$, respectively. No major differences were identified. The characteristics of particle size agree with earlier investigations on diesel engine exhaust as well as data from experimental exposures to diesel exhaust in animal studies. ${ }^{18-20}$

Data on cell counts in the bronchial portion of the BAL fluid are shown in table 2. The bronchial portion more acurately reflects the response in the airways than does the bronchoalveolar portion, which mainly lavages the alveoli. The cell data indicate that it is the airways proximal to the alveoli that are primarily involved. The total cell number in the bronchial portion was significantly increased after exposure to unfiltered exhaust, compared with exposure to air $(p<0.05)$. The increase mainly consisted of an increase in the total number of alveolar macrophages $(\mathrm{p}<0.05)$. Another macrophage effect after exposure to exhaust without the trap was a significant increase in the total number of lysozyme positive macrophages in the bronchial portion $(p<0.01)$.

In the bronchial portion neutrophils (table 2) increased after both types of exposure to diesel exhaust, compared with the exposure to air. The total number as well as the percentage of neutrophils were significantly increased after exposure to unfiltered exhaust (both $\mathrm{p}<0.02$ ). Exposure to exhaust filtered with the ceramic particle trap versus air caused a significant increase in the percentage of neutrophils $\mathrm{p}<0.05$, as well as a tendency towards an increase in the total number of neutrophils, compared with exposure to air $(\mathrm{p}=0.066)$. The numbers of lymphocytes and mast cells in the bronchial portion were unaltered after the exposures to exhaust.

Total cells, macrophages, lymphocytes, neutrophils, and mast cells in bronchial portion showed no differences between exposure with and without the particle trap.

Table 3 Lavage lymphocyte subsets of the bronchoalveolar portion (BAP) after exposure to diesel exhaust with and without the particle filter at the tail pipe $v$ exposure to air (medians (interquartile ranges))

\begin{tabular}{|c|c|c|c|c|c|c|}
\hline \multirow[b]{2}{*}{ Exposure } & \multirow{2}{*}{$\begin{array}{l}C D 4+/ C D 8+ \\
\text { ratio }\end{array}$} & \multicolumn{2}{|l|}{$C D 3+$} & \multirow[b]{2}{*}{$C D 16+C D 56+\%$} & \multirow[b]{2}{*}{$C D 19+\%$} & \multirow[b]{2}{*}{$C D 3+C D 25+\%$} \\
\hline & & $\times 10^{7} / l$ & $\%$ & & & \\
\hline \multirow[t]{2}{*}{ Air } & 1.68 & 0.18 & 55 & 4 & 2 & 10 \\
\hline & $1.44-2.05$ & $0.12-0.42$ & $49-66$ & $4-5$ & $1-2$ & $7-11$ \\
\hline \multirow[t]{2}{*}{ Diesel exhaust (filtered) } & 1.85 & 0.43 & $67^{\star}$ & 5 & 2 & 6 \\
\hline & $1.33-2.21$ & $0.28-0.54$ & $61-78$ & $3-7$ & $1-2$ & $3-12$ \\
\hline \multirow[t]{2}{*}{ Diesel exhaust (unfiltered) } & 1.85 & 0.51 & $75 \dagger$ & 5 & 1 & $6^{\star \star}$ \\
\hline & $1.46-1.92$ & $0.24-0.72$ & $60-76$ & $3-5$ & $1-3$ & $4-8$ \\
\hline
\end{tabular}

${ }^{\star} \mathrm{p}<=0.05 ;{ }^{\star \star} \mathrm{p}<0.02 ; \mathrm{tp}=0.069 v$ exposure to air. 
Table 4 Alveolar macrophage phagocytosis (BAP) in vitro after exposure to diesel exhaust with and without the particle filter at the tailpipe v exposure to air (medians (interquartile ranges))

\begin{tabular}{llll}
\hline Exposure & $\begin{array}{l}\text { Phagocytosis } \\
\text { positive cells } \\
\%\end{array}$ & $\begin{array}{l}\text { Total number of } \\
\text { ingested particles }\end{array}$ & $\begin{array}{l}\text { Adherence } \\
\text { positive cells } \\
\%\end{array}$ \\
\hline Air & 88 & 434 & 2 \\
Deisel exhaust (filtered) & $85-91$ & $311-479$ & $0-4$ \\
Diesel exhaust (unfiltered) & $82^{\star \star}$ & $216^{\star \star \star}$ & $7 \dagger$ \\
& $76-83$ & $181-255$ & $5-8$ \\
& $79^{\star \star \star}$ & $216^{\star \star \star}$ & $7^{\star}$ \\
& $73-84$ & $199-258$ & $4-8$ \\
\hline
\end{tabular}

${ }^{\star} \mathrm{p}<0.05 ;{ }^{\star \star} \mathrm{p}<0.02 ;{ }^{\star \star \star} \mathrm{p}<0.01 ; \mathrm{t} \mathrm{p}=0.077 v$ exposure to air.

In the bronchoalveolar portion, which more accurately reflects the alveoli, significant effects on cell numbers were found only in the lymphocyte subsets, examined with flow cytometry. Therefore only the lymphocyte numbers are given (table 3 ). A significant increase in the percentage of CD3 positive $\mathrm{T}$ cells were detected after exposure to exhaust filtered with a particle trap $(\mathrm{p}<0.05)$, and a similar tendency was found after exposure to unfiltered exhaust $(p=0.069)$. (CD = cluster of differentiation. $)$ The percentage of CD25 (interleukin-2 receptor) positive $\mathrm{T}$ cells was significantly suppressed after exposure to unfiltered exhaust $(p<0.02)$. The total macrophage number in the bronchoalveolar portion (data not shown) was not increased as in the bronchial portion. The total number of lysozyme positive macrophages tended to change in the same direction as in the bronchial portion-that is, an increase after exposure to unfiltered exhaust $(p=0.064)$. No significant changes in neutrophils or mast cells were seen.

There were no differences between exposure to diesel exhaust with and without the particle trap according to total cells, macrophages, lymphocytes, neutrophils, and mast cells in the bronchoalveolar portion.

Phagocytosis by alveolar macrophages in vitro was measured only on cells from the bronchoalveolar portion as there were not enough cells in the smaller bronchial portion. There were consistent reductions or tendencies to reductions in phagocytosis by alveolar macrophages after exposure to diesel exhaust with and without the particle trap (table 4). Exposure without an exhaust trap significantly reduced the number of phagocytosis positive macrophages $(p<0.01)$, the total number of ingested particles, compared with exposure to air $(p<0.01)$, and tended to increase the percentage of adherent positive macrophages $(\mathrm{p}<0.05)$. The corresponding significance levels for exhaust exposure with a ceramic trap versus air were $\mathrm{p}<0.02, \mathrm{p}<0.01$, and $\mathrm{p}=0.077$, respectively.

The particle trap compared with unfiltered exhaust did not change phagocytosis by alveolar macrophages in vitro.

The measured concentrations of the soluble components are shown in table 5. Myeloperoxidase increased slightly, but not significantly, both in the bronchial portion and the bronchoalveolar portion after both types of exposure to diesel exhaust compared with air. The finding of unaltered concentrations of tryptase and eosinophilic cationic protein suggests that degranulation of mast cells and eosinophils is not a prominent feature, at least not at the time of investigation. Fibronectin is a common nonspecific marker of inflammation that was likewise not affected. The unchanged albumin concentrations in lavage suggest no major increase in epithelial permeability to have occurred. As bronchoscopy was performed at 24 hours after exposure this represents a time frame where persisting changes may be reflected, but early inflammatory events may have been transient and no longer detectable. No significant differences were seen regarding the changes in these lung lavage parameters during the two diesel exhaust exposure regimens versus air or between exposure to diesel exhaust with and without the particle trap.

\section{Discussion}

This study confirmed the findings from our earlier investigation in which bronchoscopy was used to evaluate the effects of exposure to diesel exhaust in humans. ${ }^{7}$ We found that diesel exhaust caused an increase in neutrophils in airway lavage, together with an adverse influence on the phagocytosis by alveolar macrophages in vitro. Furthermore, the diesel exhaust was able to induce a migration of alveolar macrophages into the airspaces, together with signs of reduced $\mathrm{T}$ cell activation. These data were obtained with an exposure apperatus which has been carefully developed and validated. ${ }^{8} 9$

Current data indicate that diesel exhaust by itself is able to induce an increase in the number of neutrophils in the airways. Neutrophilia is a common event after exposures to air pollution and it has been suggested that it could be a marker of a reactive inflammatory reponse to noxious agents. This has earlier been related to the strong oxidative air pollutants, nitrogen dioxide and ozone, according to experiences by this and other groups. ${ }^{21}{ }^{22}$ Still, neutrophilia has not been detected after

Table 5 Lavage data on soluble components in the bronchial portion (BP) and bronchoalveolar portion (BAP) after exposure to air and to diesel exhaust with and without the particle filter at the tail pipe (medians (interquartile ranges))

\begin{tabular}{|c|c|c|c|c|c|c|c|c|c|c|}
\hline \multirow[b]{2}{*}{ Exposure } & \multicolumn{2}{|c|}{$M P O(\mu g / l)$} & \multicolumn{2}{|c|}{ Tryptase $(n g / l)$} & \multicolumn{2}{|l|}{$E C P(n g / l)$} & \multicolumn{2}{|c|}{ Fibronectin $(\mu g / l)$} & \multicolumn{2}{|c|}{ Albumin $(\mu g / l)$} \\
\hline & $B P$ & $B A P$ & $B P$ & $B A P$ & $B P$ & $B A P$ & $B P$ & $B A P$ & $B P$ & $B A P$ \\
\hline Air & 9.8 & 3.9 & 1.4 & 1.4 & 0.23 & 0.22 & 250 & 247 & 54 & 34 \\
\hline & $4.7-13.0$ & $3.6-8.2$ & $1.3-1.4$ & $1.3-1.5$ & $0.22-0.29$ & $0.20-0.23$ & $156-500$ & $157-320$ & $39-64$ & $27-50$ \\
\hline Diesel exhaust & 17.2 & 7.4 & 1.3 & 1.5 & 0.24 & 0.22 & 335 & 310 & 67 & 37 \\
\hline (filtered) & $8.6-22.5$ & $4.8-10.5$ & $1.3-1.4$ & $1.4-1.6$ & $0.23-0.47$ & $0.19-1.01$ & $162-613$ & $129-455$ & $41-92$ & $28-66$ \\
\hline Diesel exhaust & 13.9 & 8.5 & 1.4 & 1.3 & 0.28 & 0.22 & 320 & 250 & 63 & 45 \\
\hline (unfiltered) & $8.2-33.4$ & $3.7-11.7$ & $1.3-1.5$ & $1.2-1.4$ & $0.24-0.90$ & $0.20-0.23$ & $167-615$ & $185-370$ & $39-84$ & $34-53$ \\
\hline
\end{tabular}

$\mathrm{MPO}=$ myeloperoxidase; $\mathrm{ECP}=$ eosinophilic cationic protein 
exposure to $\mathrm{NO}_{2}$ concentrations $<1.5 \mathrm{ppm}$ during similar durations of exposure and work load, ${ }^{23}$ suggesting that particulates and other components in the diesel exhaust may be of major importance.

Alveolar macrophages are key cells in the immune defence against various microorganisms. Finding a reduced rate of phagocytosis in vitro supports the assumption that diesel exhaust does have a negative influence on important immune defence functions. Such an effect on macrophages has not been attributed to exposure to $\mathrm{NO}_{2} \cdot{ }^{10} \mathrm{~A}$ reduced capacity to ingest foreign material may be of considerable concern for the defence against harmful microorganisms, as is an impaired communication with $\mathrm{T}$ cells which need to respond to peptide derivatives presented by the macrophages during direct cell to cell interaction. Another indicator that the macrophages were indeed affected by the exhaust is the finding of an increase in the total number of macrophages in the bronchial portion. The inhalation of particles in the exhaust apparently increased the demand for phagocytosis, especially when macrophages were not acting properly. Not surprisingly the exposure to the unfiltered exhaust resulted in an increased recruitment of alveolar macrophages to the airways to increase the capacity for clearance of the inhaled particulates.

The exposure to diesel exhaust showed a tendency to increase the proportion of CD3+ cells in the lymphocyte population, and interestingly, diesel exhaust was shown to have a suppressive effect on the proportion of activated CD25 (IL-2 receptor) positive $\mathrm{T}$ cells. Whether this represents a genuine step to suppress $\mathrm{T}$ cell activity, or reflects migration of not yet activated $\mathrm{T}$ cells, cannot presently be decided.

The interventive step in this study was to evaluate the efficacy of the ceramic particle trap, to reduce the bronchoalveolar inflammatory effects of diesel exhaust. This was based on the need to find ways to reduce adverse biological effects of vehicle exhaust, for which technical intervention on the exhaust system is one of the possible pathways. Our current data suggest that the particle trap was not very effective at diminishing the proinflammatory effects of diluted diesel exhaust. Despite the use of the ceramic particle trap, the diesel exhaust tended to cause an influx of neutrophils into the airways, together with changes in CD3+CD25+ expression, as was found in unfiltered exhaust. Furthermore, the evident effects of the diesel exhaust on phagocytosis by alveolar macrophage was as pronounced after exposure to diesel exhaust with the ceramic particle trap as without. Only the finding that the total number of macrophage cells recovered in the bronchial portion was reduced by half suggested that the ceramic particle trap might have been of some benefit for the airway response. Although exposure to unfiltered diesel exhaust caused a significant increase in the number of alveolar macrophages, also reflected as an increase in the total cell number recovered, such an effect could not be identified with certainty after exposure with the ceramic particle filter. It can be argued that some people have a relatively high number of total macrophages after exposure with the filter, but as a group the $\mathrm{p}$ value was 0.39 , certainly far from significant. It can be also argued that with many subjects, the effect of the filter on macrophages could possibly have been significant compared with unfiltered exhaust versus air. If so, that would still indicate that for many people the ceramic particle trap does not protect against adverse biological effects during idling. This is also in agreement with the finding that a similar reduction of particles with the ceramic trap did not abolish the increase of airway resistance by diesel exhaust. ${ }^{9}$ It is possible that characteristics of size and composition of particles that get through the trap could have been important in the lack of effectiveness. However, it is most likely that diesel exhaust particles need to be reduced even more to achieve satisfactory protection. A ceramic particle trap of the type tested may be more efficient in the particle size range $0.05-0.4 \mu \mathrm{m}$ under certain circumstances - such as at higher speed and load. ${ }^{24}$ Even though this may be a positive feature, it is often in situations where engines are idling that high air pollution is encountered, especially in locations with low air exchange. ${ }^{11-14}$ As a consequence, there is a need for further multidisciplinary activities to develop and test additional technical approaches to reduce the unfavourable consequences by exposure to diesel exhaust.

The results of the current study confirm that exposure to diesel exhaust may induce a neutrophil recruitment into the airways and suppress macrophage function. The use of the specific ceramic particle trap at the end of the tail pipe was not sufficient to completely abolish these effects when interacting with the exhaust from an idling vehicle. The exposure model is being further used in ongoing studies to enhance the understanding of the effects of diesel exhaust in the airways and to extend the exploration of effective intervention into the effects of diesel exhaust.

We thank Lage Burström, Annika Hagenbjörk-Gustafsson, Kjell Hollström, Stefan Frisk, Torgny Lundberg, Anna Wenngren, Marianne Bryggman, Lena Skedebrant, Magdalena Friström, FOA, Umeå; Anders Magnusson, YMK, FHVC, Linköping; Henrik Landälv, Volvo, Gothenburg; Göran Olsson, Dräger Svenska AB, Enköping; Hans-Georg Horn, TSI GmbH, Aachen, Germany; and Lennart Schönning, OK, Stockholm, for technical assistance. This project was supported by grants from OK Petroleum Environmental Foundation, Sweden and Volvo Research Foundation and Volvo Educational Foundation, Sweden. The support from the Heart-Lung Fund, Swedish Council for Work Life Research, and Umeå University is also acknowledged.

1 Air pollution in the World's megacities. A report from the UN environment programme and WHO. Environment 1994;36:5-37.

2 Dockery DW, Pope A 11l, Xu X, et al. An association between air pollution and mortality in six US cities. $N$ Engl $\mathcal{F} M e d$ 1993;329:1753-9.

3 Seaton A, Mac Nee W, Donaldson K, et al. Hypothesis: particulate air pollution and acute health effects. Lancet 1995; 345:176-8.

4 United States Department of Energy. Issues concerning the light-duty diesel. Washington, DC: Department of Energy, September 1979:1-123. (DOE/EV-6050/1.)

5 Reger R, Hancock J, Hankinson J, et al. Coal miners exposed Reger R, Hancock J, Hankinson J, et al. Coal miners exposed
to diesel exhaust emissions. Ann Occup Hyg 1982;26:799815 .

6 Ayres SM, Evans R, Licht D, et al. Health effects of exposure to high concentrations of automotive emissions. Arch Environ Health 1973;27:168-78. 
7 Rudell B, Sandström T, Stjernberg N, et al. Controlled diesel exhaust exposure in an exposure chamber: pulmonary Sci 1990;21 (suppl 1):411-14.

8 Rudell B, Sandström T, Hammarström U, et al. Evaluation of an exposure setup for studying effects of diesel exhaust in humans. Int Arch Environ Health 1994;66:77-83.

9 Rudell B, Ledin M-C, Hammarström U, et al. Effects on symptoms and lung function in humans experimentally exposed to diesel exhaust. Occup Environ Med 1996;53: 658-62.

10 Sandström T. Respiratory effects of air pollutants. Experimental studies in humans. Eur Respir f 1995;8:976-95.

11 Attfield MD, Trabant GD, Wheeler RW. Exposure to diese fumes and dust at six potash mines. Ann Occup Hyg 1982

2 Ulfvarson U, Alexandersson R, Dahlqvist M, et al. Pulmonary function in workers exposed to diesel exhausts: the effect of control measures. Am f Ind Med 1991:19:283-9.

13 Rudell B, Wass U, Hörstedt P, et al. Efficiency of automotive cabin air filters to reduce acute health effects of diesel exhaust in human subjects. Occup Environ Med 1999;56: exhaust in

14 Ptak TJ, Wake J, Jaroszczyk T. An experimental evaluation of the factors influencing the performance of car interior filters. In: Climate control and automitive cabin air filtration. Anglin PE, Ilkka SJ, eds. Warrendale, PA: Society of Automotive Engineers, 1994;12994:35-43.

15 Helleday R, Sandström T, Stjernberg N. Smokers have a different bronchoalveolar cell response to nitrogen dioxide exposure compared to non-smokers. Eur Respir F 1994;7: $1213-20$.

16 Bjermer L, von Schoultz E, Norberg B, et al. Estramustine inhibits phagocytosis. Prostate 1988;13:49-55.
17 Levin JO, Lindahl R, Andersson K. A passive sampler for formaldehyde in air using 2,4-dinitrophenylhydrazinecoated glass fiber filters. Environment Science and Technology 1986;20:1273-6.

18 Kittelson DB, Dolan DF, Diver RB, et al. Diesel exhaust particle distributions-fuel and additive effects. Warrendale, PA: Society of Automotive Engineers, 1987;78:87.

19 Heinrich U, Fuhst R, Rittinghausen S, et al. Chronoc inhalation exposure of Wistar rats and two different strains of mice to diesel engine exhaust, carbon black and titanium mice to diesel engine exhaust, carb
dioxide. Inhal Tox 1995;7:533-56.

20 Mauderly JL, Snipes MB, Barr EB, et al. Pulmonary toxicity of inhaled diesel exhaust and carbon black in chronically exposed rats. Part 1: neoplastic and non-neoplastic lesions. Cambridge, MA: Health Effects Institute, 1994. (Research report No 68.)

21 Blomberg A, Krishna MT, Bocchino V, et al. The inflammatory effect of 2 ppm NO $\mathrm{NO}_{2}$ on airways of healthy subjects. $A m$ f Respir Crit Care Med 1997;156:418-24.

22 Devlin RB, McDonnell WF, Becker S, et al. Timedependent changes of inflammatory mediators in the lungs of humans exposed to $0.4 \mathrm{ppm}$ ozone for 2 hours; a comparison of mediators found in bronchoalveolar lavage fluid 1 and 18 hours after exposure. Toxicol Appl Pharmacol 1996;138:176-85.

23 Sandström T, Ledin MC, Thomasson L, et al. Reductions in bronchoalveolar lymphocyte subpopulations following repeated exposure to $1.5 \mathrm{ppm}$ nitrogen dioxide. $\mathrm{Br} F$ Ind Med 1992;49:850-4.

24 Wiczynski PD, Johnson JH. The effect of a ceramic trap on diesel particulate fractions. Warrendale, PA: Society of Automotive Engineers 1986;86:1-17.

\section{Correspondence and editorials}

Occupational and Environmental Medicine welcomes correspondence relating to any of the material appearing in the journal. Results from preliminary or small scale studies may also be published in the correspondence column if this seems appropriate. Letters should be not more than 500 words in length and contain a minimum of references. Tables and figures should be kept to an absolute minimum. Letters are accepted on the understanding that they be subject to editorial revision and shortening.

The journal also publishes editorials which are normally specially commissioned. The Editor welcomes suggestions regarding suitable topics; those wishing to submit an editorial, however, should do so only after discussion with the Editor. 